UDC 578.856

\title{
Strain attribution of Ukrainian isolates of Zucchini yellow mosaic virus and their occurrence in Ukraine
}

\author{
V. O. Tsvigun ${ }^{1}, 2$, T. O. Rudneva ${ }^{2}$, T. P. Shevchenko ${ }^{1}$, \\ I. G. Budzanivska1 ${ }^{1}$, V. P. Polishchuk ${ }^{1}$ \\ ${ }^{1}$ Educational and Scientific Center "Institute of Biology", Taras Shevchenko National University of Kyiv \\ 64/13, Volodymyrska Str., Kyiv, Ukraine, 01601 \\ 2 Institute of Agroecology of NAAS \\ 12, Metrologichna Str., Kyiv, Ukraine, 03680 \\ vika-natcevich@ukr.net
}

\begin{abstract}
Purpose. Current research was aimed at establishing the strain attribution of Ukrainian isolates of Zucchini yellow mosaic virus (ZYMV) and their occurrence in Ukraine. Methods. Visual examination, DAS-ELISA, RT-PCR, DNA sequencing, and phylogenetic analysis. Results. Plants from Cucurbitaceae family were checked for the presence of ZYMV antigens. DAS-ELISA showed that $41 \%$ of examined cucurbit plants were infected by ZYMV. The infected plants were detected in agroecosystems of Vinnytsia, Zaporizhzhia, Kyiv, Poltava and Cherkasy regions. cDNA of $605 \mathrm{bp}$ corresponding to the Nib/CP genome region of ZYMV was obtained using RT-PCR. Phylogenetic analysis of the nucleotide sequence of the Nib/CP region of Ukrainian isolates was conducted. Conclusions. The identification of infected plants in 5 of 9 inspected agroecosystems suggests high prevalence of the ZYMV infection in Ukraine. The topology of a reconstructed phylogenetic tree confirmed the previously established clustering of ZYMV isolates into three groups. The phylogenetic positioning of the Ukrainian ZYMV isolates on this tree demonstrates that they belong to a subgroup I of group A. This group is the most numerous group, which consists of members of different geographic origins. The ZYMV isolates circulating in Ukraine were found to be nearly identical: their levels of pairwise identity range from 99.7 to 100. They have a monophyletic origin with the European isolates from Austria (AJ420017), Slovenia (AJ420018), Serbia (HM072432), Hungary (AJ459955), Slovakia (DQ124239). The levels of pairwise identity between the Ukrainian and European isolates range from 94.3 to $100 \%$.
\end{abstract}

Ke yw ord s: Zucchini yellow mosaic virus, agroecosystems, strains, phylogenetic analysis

\section{Introduction}

Zucchini yellow mosaic virus (ZYMV) is one of the most economically dangerous viruses for all cucurbit crops. Thus, a biological, serological and molecular characterization of this virus is of great importance. ZYMV is widespread on all continents except Antarctica.

ZYMV belongs to Potyvirus genus of Potyviridae family. It was first described in Italy in 1973 [1]. ZYMV infects 15 plant species from 7 different fam- ilies. However, only the members of Cucurbitaceae family develop severe symptoms [2]. An occurrence of ZYMV was reported from more than 50 countries. It causes yield losses ranging from 25 to $50 \%$ depending on the pathogenicity of the virus strain. The symptoms include mosaics and yellowing leaf blade [3]. Knobs appear on fruits. Notably, in Ukraine this virus was first detected approximately 10 years ago [4].

The nucleotide sequences of approximately 400 strains and isolates of ZYMV were published in

(C) 2016 V. O. Tsvigun et al.; Published by the Institute of Molecular Biology and Genetics, NAS of Ukraine on behalf of Biopolymers and Cell. This is an Open Access article distributed under the terms of the Creative Commons Attribution License (http://creativecommons.org/licenses/by/4.0/), which permits unrestricted reuse, distribution, and reproduction in any medium, provided the original work is properly cited 
GenBank. The nucleotide sequences of the coat protein $(\mathrm{CP})$ and polymerase (NIb) genes as well as the amino acid sequences of their products are commonly used to establish a phylogenetic relationship between ZYMV strains. According to the literature data, the $\mathrm{N}$-terminal part of $\mathrm{CP}$ is more variable than the C-terminal part of the NIb genome region [5]. Moreover, the selection pressures were shown to be different: it was ten times higher for the C-terminal part of NIb than for the variable N-terminal part of CP.

According to the topology of phylogenetic tree built using the Nib/CP genome region, the ZYMV isolates form three distinct groups: A, B and C [5]. Group A consists of three clusters supported on the phylogenetic tree by bootstrap of relatively high values. Cluster I includes the most frequently detected strains. Most of them belong to the serotype 1. The proposed referent strain of this subgroup is ZYMVNAT. Cluster II is not supported by high bootstrap values. However, three different methods of phylogenetic analysis estimated the distinction of this cluster. The members of cluster II cannot be distinguished by serological tests, since all mutations in the coat protein gene sequences are synonymous; the amino acid sequences are identical. The strains of cluster III are presented by a small proportion of the ZYMV isolates, which were detected on four continents and connected with the strains of other clusters from Austria, Italy and Spain [5].

Group B includes one cluster consisted of five isolates from Reunion and neighboring islands, which differ from other isolates $[5,6]$. Group C consists of several Chinese, Polish and Australian isolates.

Viral infection leads to an increase in the number of infected plants, decreases the quality of fruits and causes losses of yield. As ZYMV are widespread in the world, it is important to analyze phylogenetic relationships between Ukrainian isolates and the reported strains of this virus to propose possible ways of ZYMV dissemination from other countries to Ukraine as well as from Ukraine to other countries.

The purpose of current study was to establish the strain attribution of Ukrainian isolates of ZYMV and to examine their occurrence in Ukraine.

\section{Materials and Methods}

Plant samples were collected following the visual examination of virus symptoms. The equal number of samples was collected from each location. Plant material was homogenized in 0.1 phosphate buffered saline (PBS), pH 7.4, 1:2 (m/v). Plant components were removed by centrifugation at $5000 \mathrm{~g}$ for $20 \mathrm{~min}$ at $4{ }^{\circ} \mathrm{C}$ using centrifuge PC-6 [7]. The supernatant was taken for diagnostic tests. Double-antibody sandwich enzyme-linked immunosorbent assay (DAS-ELISA) was used for detection of viral antigens. DAS-ELISA was performed using commercial test system of Loewe (Germany) according to the manufacturer's recommendations. The ELISA results were read at 405/630 nm using microplate reader Termo Labsystems Opsis MR (USA) with Dynex Revelation Quicklink software. For obtaining statistically significant results, three times repeated testing of each sample was performed [8]. Arithmetic mean was calculated for each sample [9].

Total RNA was extracted from plant samples using RNeasy Plant Minikit (Qiagen, Great Britain) [10]. Reverse transcription polymerase chain reaction (RT-PCR) was carried out using primers specific to $\mathrm{Nib} / \mathrm{CP}$ genome region of ZYMV [5]:

Forward primer -5 '-ATGTCGAGTATCACATTTCC-3”;

Reverse primer -5 ' GGTTCATGTCCCACCAAGC-3’

These primers are complementary to $8200-8220$ and 8800-8819 positions of genome and allow amplifing the fragments of $605 \mathrm{bp}$ encompassing the C-terminal part of $\mathrm{Nib}$ coding region and the $\mathrm{N}$-terminal part of the coat protein coding region.

RT-PCR was performed in the following parameters: $30 \mathrm{~min}$ at $50^{\circ} \mathrm{C}$, followed by 30 cycles $-1 \mathrm{~min}$ at $95{ }^{\circ} \mathrm{C}, 30 \mathrm{~s}$ at $95{ }^{\circ} \mathrm{C}, 30 \mathrm{~s}$ at $55^{\circ} \mathrm{C}$, and final cycle $-1 \mathrm{~min}$ at $72{ }^{\circ} \mathrm{C}$. RT-PCR products were analyzed by electrophoresis in $1.5 \%$ agarose gel using markers Gene Ruller 100 bp DNA Ladder plus (Fermentas, USA) [11]. Obtained amplicons were extracted from agarose gel and purified using Thermo Scientific GeneJET Extraction Kit (USA). The purified amplicons were sequenced using 
Applied Biosystems 3730x1 DNA Analyzer with Big Dye terminators, version 3.1 (Applied Biosystems, USA).

Finally, we obtained Nib/CP sequences of the following Ukrainian isolates: ZYMV-10G (extracted from Cucurbita pepo in Poltava region), ZYMV-10P (extracted from Cucumis melo in Vinnytsia region), ZYMV-38/14 (extracted from Citrullus lantanus in Cherkasy region), ZYMV 5/13 (extracted from Cucurbita pepo in Poltava region) and ZYMV-B (extracted from Cucumis melo in Cherkasy region). The obtained nucleotide sequences were compared with their homologs from the strains reported from different countries using NCBI. The nucleotide sequences were analyzed using MEGA 6 software. The sequences were aligned by CLUSTAL W. Tree branches were bootstrapped with 1,000 replications [12].

A

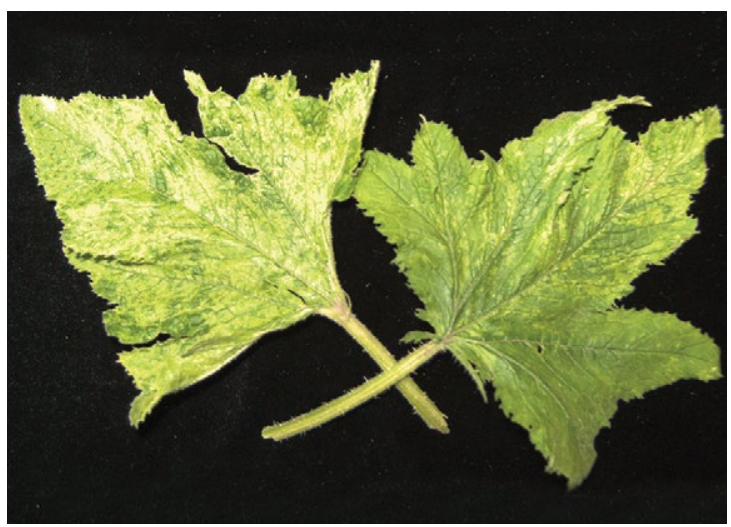

C

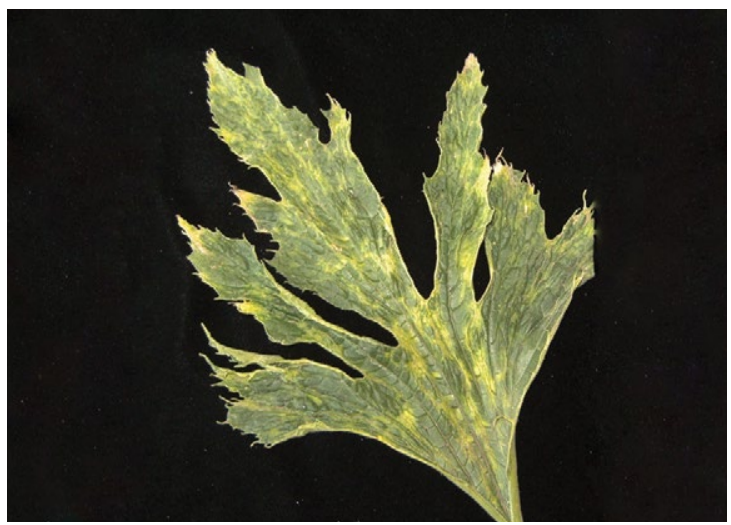

\section{Results and discussion}

126 samples of plants from Cucurbitaceae family were screened for the presence of viral antigens. The plant samples were collected in agroecosystems of different regions of Ukraine: Vinnytsia, Zaporizhzhia, Kyiv, Kirovohrad, Odessa, Poltava, Cherkasy and Chernihiv. Cucurbit plants (cucumbers, squashes, pumpkins, and zucchini) showed the following symptoms: puckering, distortion, vein banding, yellowing, filamentary, yellow mosaic on leaf blade; dark green spots of different size, knobs and malformations on fruits (Fig.1).

Further, DAS-ELISA was performed for detection of ZYMV. Antigens of ZYMV were detected in 51 plant samples out of 126. Zucchini yellow mosaic virus was detected in the mixed infections with Watermelon mosaic virus- 2 and Cucumber mosaic virus.

B

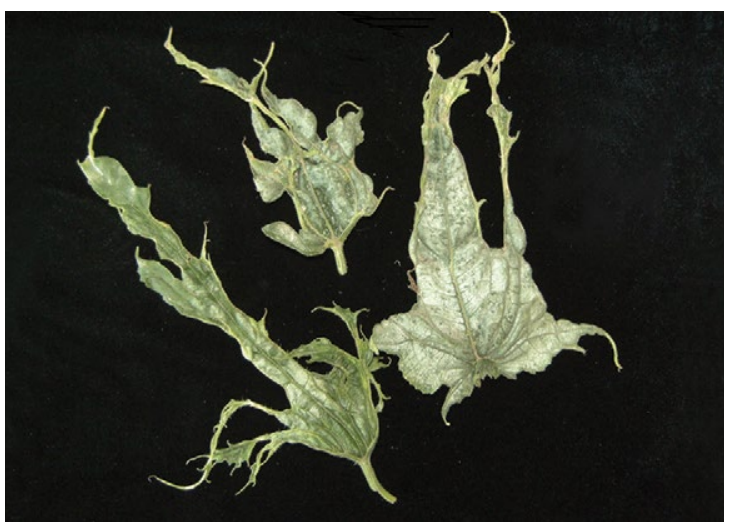

D

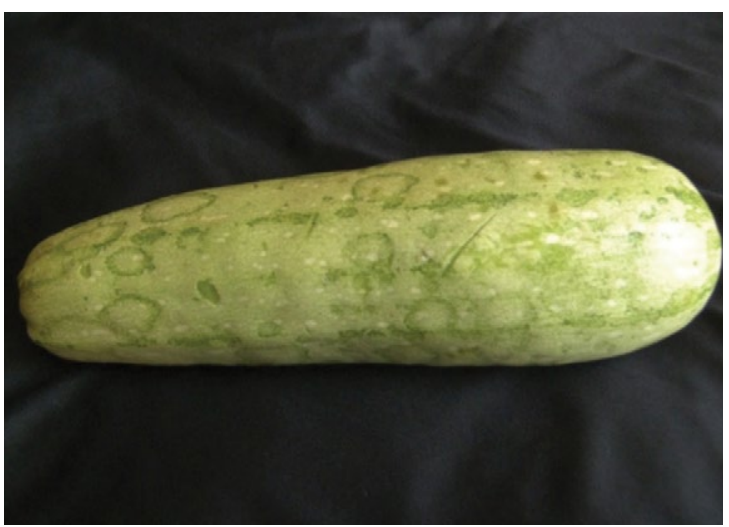

Fig. 1. Symptomatic plants from Cucurbitaceae family: dark green mosaic on leaf blade of Cucurbita pepo; filamentary of leaf blade of Cucurbita pepo; light green mosaic on leaves of Cucurbita pepo; knobs and ring spots on fruit of Cucurbita pepo. 
The survey conducted in 9 regions demonstrated that ZYMV is widespread in the central area of our country (Kyiv, Vinnytsia, Cherkasy and Poltava regions) as well as in Zaporizza region. ZYMV infection was not detected either in the northern (Chernigiv region) or in the southern (Kirovograd, Odessa regions) areas of Ukraine (Fig.2). These finding allows a preliminary conclusion that the epidemiological situation with regard to ZYMV is likely more favorable in the latter regions, although more detailed studies on the ZYMV distribution are needed to confirm this suggestion. In any case, the detection of ZYMV infection in five of nine inspected regions points on a quite high prevalence of ZYMV in Ukraine.

The total RNA was extracted from the following plant samples: Cucurbita pepo from Poltava region (isolate ZYMV-10G), Cucumis melo from Vinnytsia region, Citrullus lantanus from Cherkasy region (ZYMV 38/14), Cucurbita pepo from Poltava region (isolate ZYMV 5/13) and Cucumis melo from Cherkasy region (isolate ZYMV-B).

The obtained sequences overlap the NIb/CP cleavage site at position 8542 . This fragment is commonly used to study the variability of potyviruses, because the N-terminal part of the coat protein is known to be highly variable, whereas the polymerase is more conserved. RT-PCR resulted in amplification of a cDNA of expected $605 \mathrm{bp}$.

Further, the obtained amplicons were sequenced for establishing their phylogenetic relationships. The

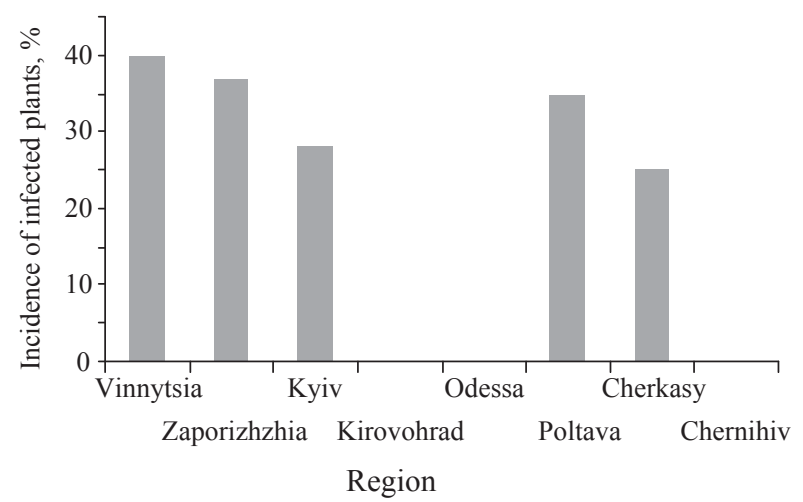

Fig. 2. Incidence of plants from family Cucurbitaceae infected by Zucchini yellow mosaic virus.

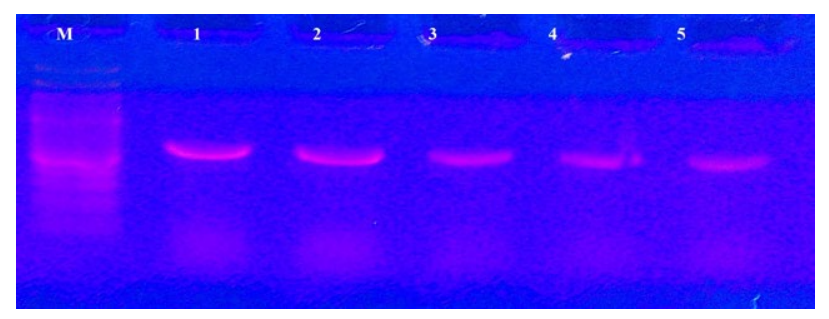

Fig. 3. The electrophoregram of cDNA obtained in RT-PCR: $1-$ ZYMV 38/14, 2- ZYMV 5/13, 3 - ZYMV 10P, 4 - ZYMV 10G, 5 - ZYMV B, $M$ - markers (100 bp, Fermentas).

sequences were compared with the $\mathrm{Nib} / \mathrm{CP}$ sequences of ZYMV strains and isolates previously reported in GenBank. The strains and isolates selected for phylogenetic analysis have different geographic origin, group attribution, biological and serological properties. The levels of identity between Ukrainian isolates and 49 isolates from GenBank ranged from 58 to $100 \%$. The phylogenetic tree was constructed using Neighbor-Joining method in MEGA 6 (Fig. 4).

The phylogenetic analysis revealed that Ukrainian isolates have low level of variability of the $\mathrm{Nib} / \mathrm{CP}$ genome region: level of identity between Ukrainian isolates is $99,7 \%$.

According to the literature data, all isolates were proposed to be distinguished into three groups, and within group A four subgroups were separated by G. Romay (2014). The topology of resulted phylogenetic tree confirmed this grouping: three the most numerous clusters consisted of four subclusters [6]. Ukrainian isolates were located in subgroup I within group A. Besides Ukrainian isolates, this subgroup also included isolates from Austria (AJ420017), Slovenia (AJ420018), Serbia (HM072432), Hungary (AJ459955), Slovakia (DQ124239) and Venezuela (JX310104 VE10-303, JX310118 VE10279, JX310109 VE10-290, JX310108 VE10-292, JX310116 VE10-295). The levels of identity between the members of subgroup I were shown to vary from 94.3 to $100 \%$. The ZYMV isolates circulating in Ukraine have a monophyletic origin with European isolates.

Subgroup II consisted of isolates from France (JN861004), Pakistan(AB127936), Taiwan(AF127934, AF127929), Korea (AJ429071) and China (AJ316228). 
They showed the levels of identity with Ukrainian isolates ranging from 76.1 to $94.3 \%$.

Subgroup III included isolates from USA(D13914, HM768195, D00692), France (JN861005, JN861008), India (GQ251520), Australia (JF792442), Martinia (JN861006), Spain (DQ645729), China (AF513551), and Poland (EU561044). Isolates of subgroup III and Ukrainian isolates shared $90.3-94.3 \%$ identity.

Subgroup IV was presented by isolates from China (AY611022, AF486823), Korea (AF062518,
AY278998), France (JN861009) and Japan (AB004640). Levels of identity between them and Ukrainian isolates ranged from 88.1 to $95.5 \%$.

Group B consisted of isolates from Vietnam (DQ925450), Reunion(L29569), Singapore(AF014811) and Australia (JF 797208, JF 792365, JF 792368, JF 792366). Level of identity between them and Ukrainian isolates was found to range from 72.7 to $79 \%$.

Group C included isolates from China (AJ889244, AF513552, AY074808), Vietnam (DQ92450,

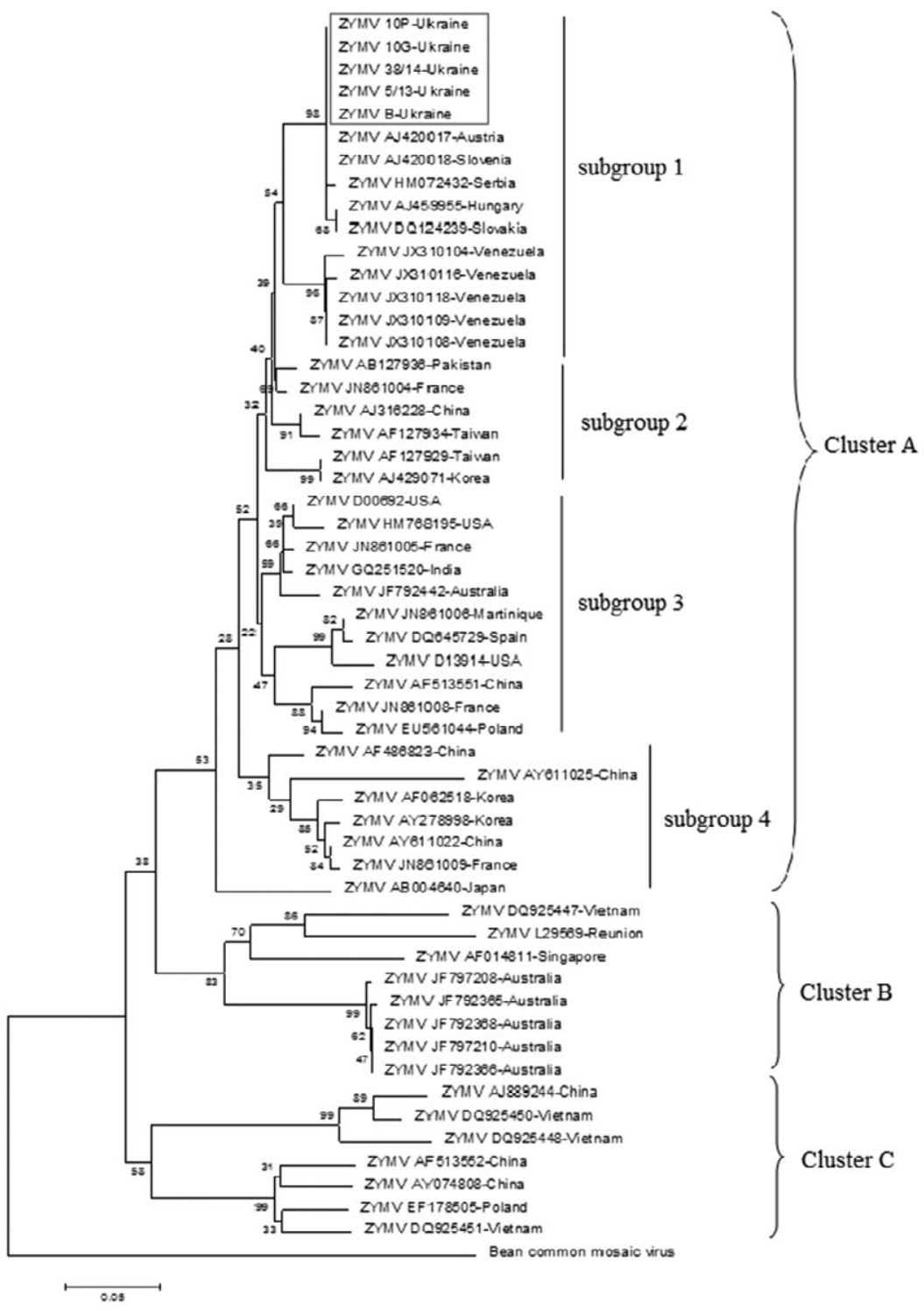

Fig. 4. Phylogenetic tree based on nucleotide sequences of Nib/CP genome region of strains and isolates ZYMV. It was built using p-distance model NeighborJoining method in MEGA 6. Bootstrap analysis was applied using 500 bootstrap samples. Numbers at nodes indicate bootstrap values. The phylogenetic tree was rooted with Bean common mosaic virus isolate MS 1 (EU761198). Three groups (A-C) and, within group A, four subgroups (I-IV) are shown. 
DQ925448, DQ925451) and Poland (EF178505). Ukrainian isolates showed $58-77.8 \%$ identity with members of this group. The lowest level of identity was shown with isolates from Vietnam (58\%).

Phylogenetic analysis of Ukrainian isolates points out that the nucleotide sequence of $\mathrm{Nib} / \mathrm{CP}$ shared high level of identity between each other and previously published strains and isolates of ZYMV. They showed the level of identity ranging from 72.7 to $100 \%$.

\section{Conclusions}

Identification of infected plants in five of nine inspected agroecosystems suggests quite high prevalence of ZYMV infection in Ukraine. The topology of reconstructed phylogenetic tree confirmed the previously established clustering of the ZYMV isolates into three groups. Phylogenetic positioning of the Ukrainian ZYMV isolates on this tree demonstrated that they belong to subgroup I of group A. This group is the most numerous group, which consists of members of different geographic origin. The highest levels of identity were revealed between Ukrainian isolates and isolates from Austria (100\%), Slovenia (96 \%), Serbia (100 \%), Hungary (99.4\%), Slovakia $(99.4 \%)$. This fact clearly indicates that Ukrainian isolates have an European origin. ZYMV are transmitted by seeds. Contaminated seed material may be considered as a possible way of introduction of new strains in Ukraine as well as from Ukraine to other countries and continents.

\section{REFERENCES}

1. Desbiez C, Lecoq H. Zucchini yellow mosaic virus. Plant Pathol. 1997; 46(6):809-29.

2. Fauquet C, Mayo MA, Maniloff J, Desselberger U, Ball LA. Virus taxonomy. VIIIth Report of the International Committee on Taxonomy of Viruses. London: Academic Press, 2004. $1162 \mathrm{p}$.

3. Gal-On A. Zucchini yellow mosaic virus: insect transmission and pathogenicity -the tails of two proteins. Mol Plant Pathol. 2007;8(2):139-50.

4. Rudneva TO, Shevchenko TP, Boyko AL. Vlastyvosti virusu zhovtoi mozaiky cukkini, izolovanogo z roslyn rodyny $\mathrm{Cu}-$ curbitaceae. Agroekologichnyy Zhurnal. 2008. Sp ed:205-7.

5. Desbiez C, Wipf-Scheibel C, Lecoq H. Biological and serological variability, evolution and molecular epidemiology of
Zucchini yellow mosaic virus (ZYMV, Potyvirus) with special reference to Caribbean islands. Virus Res. 2002;85(1):516.

6. Romay G, Lecoq H, Geraud-Pouey F, Chirinos DT, Desbiez $C$. Current status of cucurbit viruses in Venezuela and characterization ofVenezuelan isolates of Zucchini yellow mosaic virus. Plant Pathology. 2014;63 (1):78-87.

7. Polischuk VP, Budzanivska IG, Shevchenko TP. Posibnyk praktychnyh zanyatt do kursu «Zagalna Virusologia». Kyiv: "Fotosociotsentr", 2005; 129-133.

8. Antibodies. A practical approach. Ed Catty D. IRL Press, 1989; $280 \mathrm{p}$.

9. Gnutova $R V$. Serologia i immunokhimia virusov rasteniy. M.: Nauka, 1993. 301 p.

10. QIAGENR. One step RT-PCR Kit Handbook. Quiagen, 2002. 39p.

11. Safaeizadeh M. Comparative biological and molecular variability of Zucchini yellow mosaic virus in Iran. Asian $J$ Plant Pathol. 2008; 2(1):30-3.

12. Tamura K, Stecher G, Peterson D, Filipski A, Kumar S. MEGA6: Molecular Evolutionary Genetics Analysis version 6.0. Mol Biol Evol. 2013;30(12):2725-9.

\section{Встановлення штамової приналежності українських ізолятів вірусу жовтої мозаїки цукіні та їх поширення на території України}

В. О. Цвігун, Т. О. Руднєва, Т. П. Шевченко, І. Г. Будзанівська, В. П. Поліщук

Мета. Встановити штамову приналежність українських ізолятів вірусу жовтої мозаїки цукіні та дослідити їх поширення на території України. Методи. У роботі були використані наступні методи: візуальна діагностика, імуноферментний аналіз, 3ТПЛР, сиквенування та філогенетичний аналіз. Результати. Перевірено рослини родини Cucurbitaceae на наявність антигенів вірусу жовтої мозаїки цукіні (ВЖМЦ). У результаті проведених досліджень встановлено, що 41 \% перевірених рослин родини Cucurbitaceae уражені вірусом жовтої мозаїки цукіні. Вірусінфіковані рослини були наявні в агроценозах Вінницької, Запорізької, Київської, Полтавської та Черкаської областей. У результаті проведення 3Т-ПЛР було отримано продукти ампліфікації розміром 605 п.о., що відповідає за розміром ділянці геному, яка кодує Nib/CP вірусу жовтої мозаїки цукіні. За результатами даних сиквенсу побудувано філогенетичне дерево виділених ізолятів ZYMV. Висновки. Ідентифікація інфікованих рослин у 5 із 9 обстежуваних агроценозів показала широке розповсюдження ZYMV в Україні. Топологія філогенетичного дерева показує, що ізоляти ZYMV формують три групи. Філогенетичне положення на дереві українських ізолятів ZYMV показує їх приналежність до групи А підгрупи 1. Ця група $є$ найбільш чисельною та ії представники мають широке географічне поширення. Ізоляти ZYMV, що циркулюють в Україні, виявилися близькоспоріднені між собою. Відсоток 
ідентичності між ними знаходиться в діапазоні від 99,7 до 100. Дані ізоляти ZYMV мають спільне походження з європейськими ізолятами з Австрії (АЈ420017), Словенії (АЈ420018), Сербії (НM072432), Угорщини (АJ459955), Словаччини (DQ124239). Відсоток ідентичності між українськими та європейськими ізолятами знаходиться в межах від 94,3 до 100.

К л юч о в і с сл о в а: вірус жовтої мозаїки цукіні, агроценози, штами, філогенетичний аналіз.

\section{Определение штаммовый принадлежности украинских изолятов вируса желтой мозаики цуккини и их распространение на территории Украины}

В. А. Цвигун, Т. А. Руднева, Т. П. Шевченко, И. Г. Будзанивская, В. П. Полищук

Цель. Определить штаммовую принадлежность украинской изолятов вируса желтой мозаики цуккини и исследовать их распространение на территории Украины. Методы. В работе были использованы следующие методы: визуальная диагностика, иммуноферментный анализ, ОТ-ПЦР, сиквенирование и филогенетический анализ. Результаты. Проверены растения семейства Cucurbitaceae на наличие антигенов вируса желтой мозаики цуккини (ВЖМЦ). В результате проведенных исследований установлено, что 41 \% проверенных растений семейства Cucurbitaceae поражен вирусом желтой мозаики цуккини. Вирусинфицированные растения имелись в агроценозах Винницкой, Запорожской, Киевской, Полтавской и
Черкасской областей. В результате проведения ОТ-ПЦР были получены продукты амплификации размером 605 п.о., что соответствует по размеру участку генома, кодирующему $\mathrm{Nib} / \mathrm{CP}$ вируса желтой мозаики цуккини. По результатам данных сиквенирования построили филогенетическое дерево выделенных изолятов ZYMV. Выводы. Идентификация инфицированных растений в 5 из 9 обследуемых агроценозов показала широкое распространение ZYMV в Украине. Топология филогенетического дерева показывает, что изоляты ZYMV формируют три группы. Филогенетическая позиция на этом дереве изолятов ZYMV показывает их принадлежность к группе А подгруппы 1. Эта группа является наиболее многочисленной и ее представители имеют широкое географическое распространение. Данные изоляты ZYMV оказались близкородственными между собой. Процент идентичности между ними находился в диапазоне от 99,7 до 100. Изоляты ZYMV, циркулирующие в Украине, имеют общее происхождение с европейскими изолятами из Австрии (АЈ420017), Словении (АЈ420018), Сербии (НМ072432), Венгрии (AJ459955), Словакии (DQ124239). Процент идентичности между украинскими и европейскими изолятами находится в пределах от 94,3 до 100.

К л юч е в ы е с л о в а: вирус желтой мозаики цуккини, штаммы, филогенетический анализ. 